\title{
Coverage of the Domain Problem of Scientific Results' Approbation in Scientometric Databases Scopus and Web of Science
}

\author{
Oksana Romakh \\ PhD, Assistant Professor at the Department of Social Communications, \\ Institute of Journalism, \\ Taras Shevchenko National University of Kyiv, \\ 36/1 Yurii Illienko St., 04119 Kyiv, Ukraine. \\ ORCID: 0000-0002-3310-3634. \\ Email:karpati@ukr.net
}

\begin{abstract}
The article is devoted to the study of problematic aspects in the publication of materials in journals indexed in the scientometric databases Scopus and Web of Science by scientific and scientificpedagogical workers. The Ministry of Education and Science of Ukraine believes that it is not necessary to rely on quantitative indicators (it is even necessary to abandon them), and the place of publication of the article should be unimportant. At the same time, the Ministry of Education and Science establishes norms according to which it is impossible to obtain a scientific title, academic degree and be a member of a specialized scientific council without publications in scientometric databases Web of Science and / or Scopus. In the field of social communications (journalism) the problem is exacerbated by the fact that in Ukraine there are no professional journals that would be included in such scientometric databases. The purpose of the study is to identify and describe the components of the modern problem of approbation of scientific results in scientometric databases Scopus and Web of Science (in the field of «journalism»). To achieve this goal, we set the following tasks: to analyze the regulations, which contain instructions / advice / guidelines / standards for publication in the journals of the database Scopus and Web of Science; to identify the attitude of scientific and scientific-pedagogical workers working in the field of «journalism» to the problem of approbation of scientific results in such journals; identify motives and obstacles to the publication of articles in indexed journals. The main result of the article is to highlight the following problematic aspects: ambiguous position and strategy of the state to measure the quantity and quality of scientific papers; lack of encouragement of scientific and scientificpedagogical workers to publish in indexed publications with simultaneous compulsion to publish there; high cost of publication and lack of any support from the state in publishing articles; low quality of scientific works submitted to such publications and non-recognition of this problem by the community. KEYWORDS: scientometric bases; Scopus and Web of Science; indexed journals; problems in publishing; approbation problems.
\end{abstract}




\title{
Висвітлення галузевої проблеми апробації наукових результатів у наукометричних базах Scopus i Web of Science
}

\author{
Ромах Оксана Володимирівна, асистентка кафедри соціальних комунікацій Інституту \\ журналістики Київського національного університету імені Тараса Шевченка. \\ ORCID: 0000-0002-3310-3634.
}

Email: karpati@ukr.net

\section{Резюме}

Стаття присвячена дослідженню проблемних аспектів у публікуванні матеріалів у журналах, індексованих у наукометричних базах Scopus i Web of Science, науковими та науково-педагогічними працівниками. Мета дослідження - визначити й описати складові частини сучасної проблеми апробації наукових результатів у наукометричних базах Scopus та Web of Science (у галузі «журналістика»). Для досягнення мети поставлено такі завдання: пропроаналізувати нормативні документи, в яких є вказівки/поради/настанови/нормативи щодо публікування в журналах бази Scopus i Web of Science; виявити ставлення наукових та науково-педагогічних працівників, які працюють у галузі «журналістика», до проблеми апробації наукових результатів у таких журналах; визначити мотиви і перешкоди у публікуванні статей в індексованих журналах. Основним результатом статті є виокремлення таких проблемних аспектів: неоднозначна позиція і стратегія держави щодо визначення кількості та якості наукових праць; відсутність заохочення наукових і науково-педагогічних працівників до публікування в індексованих виданнях 3 одночасним примусом там публікуватися; висока вартість публікації та відсутність будь-якої підтримки з боку держави у публікуванні статей; низька якість наукових робіт, які подають до таких видань, та невизнання у спільноті цієї проблеми.

Ключові слова: наукометричні бази; Scopus i Web of Science; індексовані журнали; проблеми в опублікуванні; проблеми апробації.

\section{Вступ}

Питання вимірювання ефективності та якості роботи гостро стоїть у всіх сферах людської діяльності, наукова не є винятком. Оцінити, наскільки успішною є робота вченого, намагаються як роботодавці, так і самі працівники наукових чи освітніх установ, для того, щоб мати уявлення про раціональність напрямів діяльності, про можливості, успіхи та невдачі працівників. Нині існує кілька десятків наукометричних інструментів, однак жоден iз них не є вичерпним джерелом бібліометричних даних. Серед таких інструментів варто виділити найавторитетніші інформаційні корпорації Google, Elsevier, Clarivate Analitics, які є власниками наукометричних систем Google Scholar, Scopus, Web of Science (WoS), що за обсягами накопичених у них наукових ресурсів не мають собі рівних і $є$ фактично монополістами у сфері бібліометричної статистики (Жабін, 2020). Останніми роками набуло ваги оцінювання діяльності університетських науково-педагогічних співробітників саме 3 позиції індексу цитування публікацій у журналах, які індексуються в міжнародних 
бібліометричних базах Web of Science та Scopus (для цього, зокрема, використовується індекс Гірша) (Старостіна, Осецький, \& Кравченко, 2018).

Незважаючи на те, що «наукометричні показники носять статистичний характер, їх застосування для оцінення окремого вченого або невеликого колективу може давати яку завгодно велику похибку в будь-який бік». (Тарасевич, \& Шиняева, 2015). В Україні прийнято визначати успішність того чи іншого науковця саме за кількістю публікацій у журналах, які індексуються в наукометричних базах Scopus та/чи WoS. Насамперед це закріплено у державних нормативних документах.

Так, відповідно до «Порядку присвоєння вчених звань науковим і науково-педагогічним працівникам», затвердженого наказом Міністерства освіти і науки України 14 січня 2016 року № 13, одним із критеріїв оцінювання науково-педагогічної діяльності здобувачів учених звань визнано саме наявність публікацій у Scopus та/чи WoS. На звання професора й старшого дослідника потрібно мати не менше двох таких публікацій; на звання професора наукових установ - не менше трьох; на звання доцента - не менше однієї; і найбільше, чотири статті, необхідно мати, щоб здобути вчене звання професора працівникам вищих навчальних закладів, яким не присуджено ступеня доктора наук.

Згідно з наказом Міністерства освіти і науки України від 23 вересня 2019 року № 1220 «Про опублікування результатів дисертацій на здобуття наукових ступенів доктора i кандидата наук» для здобуття звання доктора наук необхідно «не менше ніж три статті, а 3 01 вересня 2022 року не менше ніж п'ять статей з наукового напряму, за яким підготовлено дисертацію здобувача, опублікованих щонайменше у двох різних періодичних виданнях, включених до категорії «А» Переліку наукових фахових видань України, або у закордонних виданнях, проіндексованих у базах даних Web of Science Core Collection та/або Scopus».

Згідно 3 «Порядком підготовки здобувачів вищої освіти ступеня доктора філософії та доктора наук у закладах вищої освіти (наукових установах)», затвердженим постановою Кабінету Міністрів України від 23 березня 2016 р. № 261, кваліфікація особи, що відповідає спеціальності, з якої відкрито докторантуру, визначається, зокрема, й за наявністю не менше однісї статті у періодичному виданні, включеному до наукометричних баз даних Scopus або Web of Science Core Collection.

Постановою МОН «Про присудження ступеня доктора філософії» від 6 березня 2019 р. № 167 встановлено, що «вчений, який пропонується до складу ради, повинен мати не менше трьох наукових публікацій, опублікованих за останні п'ять років, за науковим напрямом, за яким підготовлено дисертацію здобувача, з яких не менше однієї публікації у виданнях, проіндексованих у базах даних Scopus та/або Web of Science Core Collection».

Незважаючи на державну політику, що передбачає спрямованість на підтримку працівників, які публікуються в індексованих журналах, в деяких нормативних актах ми зафіксували суперечності.

Говорячи про причини кризи академічної доброчесності в державі, у «Розширеному глосарії термінів та понять ст. 42 «Академічна доброчесність» Закону України «Про освіту» (від 5 вересня 2017 р.)» виокремлено, зокрема, й «надмірні вимоги законодавства та внутрішніх нормативних документів щодо кадрового забезпечення, кількості публікацій, обсягів кваліфікаційних та інших навчальних робіт тощо».

У листі МОН щодо рекомендацій з академічної доброчесності для закладів вищої освіти № 1/9-650 від 23.10.2018 серед таких причин називається й «орієнтація вищої освіти на кількісні показники («вал»), папери, дипломи тощо, а не на якість, конкурентоздатність, корисність для суспільства тощо».

Держава закликає віддавати перевагу якісним, а не кількісним показникам у процесі планування наукової та методичної роботи викладачів закладів вищої освіти. Також «варто максимально відмовлятися від таких показників, як кількість опублікованих тез конференцій, методичних рекомендацій (безвідносно до потреби), наукових статей (безвідносно до місця публікації), монографій (безвідносно до видавництв) тощо. Ще більш 
шкідливим $є$ оцінювання науково-педагогічних працівників за кількістю сторінок чи друкованих аркушів в опублікованих ними наукових працях».

В наступному ж абзаці викладена протилежна думка: «необхідно стимулювати публікації у провідних наукових виданнях, що за імпакт-фактором чи аналогічними показниками наукометричних баз Web of Science та Scopus потрапляють до першогодругого квартилів з відповідної тематики, високі показники цитування публікацій науковопедагогічних працівників (без самоцитування та цитування співавторами) у виданнях, що індексуються зазначеними базами».

Отже, МОН України говорить про те, що покладатися на кількісні показники не варто (навіть необхідно відмовитися від них), а місце публікації статті взагалі має бути неважливим, одночасно встановлюючи норми, за яких неможливо отримати наукове звання, вчений ступінь і бути членом спеціалізованої вченої ради без публікацій у наукометричних базах Web of Science та/чи Scopus. У галузі соціальних комунікацій (журналістика) проблема загострюється ще й тим, що в Україні немає фахових журналів, які б входили до таких наукометричних баз. Існує журнал «Психолінгвістика» в базі Web of Science, який ніби можна зарахувати (у рецензентах є доктори наук із соціальних комунікацій), але суто галузеві публікації, що не стосуються психолінгвістики (а це окрема наука), редактори відхиляють як такі, що не відповідають тематиці журналу, що логічно.

Тож бачимо, що ситуація неоднозначна і потребує вивчення не лише нормативних документів, а й думок галузевої спільноти щодо нових стандартів і реального життя згідно 3 ними. Важливий також досвід колег (або його відсутність) щодо публікацій у базах WOS та Scopus.

\section{Методи}

Для обгрунтування проблеми апробації наукових результатів у наукометричних базах Scopus та Web of Science ми використали аналіз як основний метод вивчення нормативних документів - окрім державних документів ми також проаналізували звіт ректора Київського національного університету імені Тараса Шевченка, щоб установити рівень закцентованості одного 3 найкращих 3ВО України, в якому найбільша спільнота науково-педагогічних працівників із журналістики, на публікаціях в індексованих журналах. Для дослідження ставлення, мотивів та перешкод у публікуванні в таких журналах було використано метод опитування, яке відбувалось у формі анкетування.

Опитування було дистанційним, проводилося за допомогою онлайн-опитувальника; вибірковим (процедура утворення вибіркової сукупності - «снігова куля»); структура запитань анкети - змішана. Анкетування тривало два місяці - з лютого до квітня. Умовою припинення анкетування була відсутність будь-який нових відповідей протягом двох тижнів. Таким чином, усього в опитуванні взяло участь 179 респондентів.

\section{Результати}

Першим питанням анкети було встановлення наукової кваліфікації респондентів (рис. 1).

Акцентуємо увагу на найбільшому значенні відповіді: 43,6\% всіх респондентів кандидати наук (доктори філософії), які не працюють над докторською. Вважаємо недоліком нашого опитування відсутність уточнювального запитання «3 яких причин Ви не працюєте над докторською дисертацією?», адже, цілком імовірно, необхідність публікуватись у наукометричних базах відіграла важливу роль у такому рішенні. Водночас відсутність бажання працювати над докторською в момент проходження опитування не означає, що в цих респондентів з часом не виникне таке бажання. 


\section{Наукова кваліфікація респондентів}

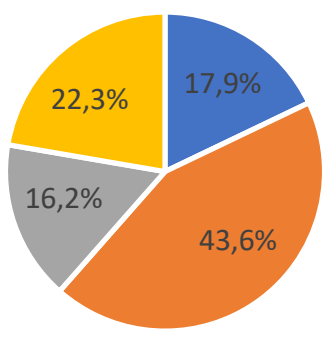

- Готує дисертацію на здобуття доктора філософії.

- Кандидат наук (доктор філософії), над докторською не працює.

- Кандидат наук (доктор філософії),готує докторську дисертацію.

- Доктор наук

\section{Рисунок 1.}

На рис. 2 можемо бачити: 40\% вважають, що працівник ЗВО має займатися науковою діяльністю на будь-якій посаді, що відповідає позиції держави з цього питання. Друга за поширеністю відповідь - людина має обирати, чи займатися науковою діяльністю. Меншість вважає, що викладачі мають тільки викладати.

\section{Чи має викладач займатися науковою діяльністю (в ідеалі)?}

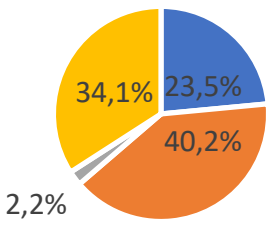

- Так, якщо він обіймає посаду доцента чи професора.

- Так, на будь-якій посаді.

- Ні, має займатись лише викладацькою діяльністю.

- Має обирати чи займатись чи ні.

\section{Рисунок 2.}


Згідно зі статтею 1, п. 25 Закону України «Про наукову і науково-технічну діяльність» (Відомості Верховної Ради (ВВР), 2016, № 3, ст. 25). «науково-педагогічний працівник вчений (виділення наше - О. Р.), який має вищу освіту не нижче другого (магістерського) рівня, відповідно до трудового договору (контракту) в університеті, академії, інституті професійно провадить педагогічну та наукову або науково-педагогічну діяльність та має відповідну кваліфікацію незалежно від наявності наукового ступеня або вченого звання, підтверджену результатами атестації у випадках, визначених законодавством». Згідно 3 постановою Кабінету Міністрів України від 14 червня 2000 р. № 963 «Про затвердження переліку посад педагогічних та науково-педагогічних працівників», посади науковопедагогічних працівників вищих навчальних закладів III-IV рівня акредитації можуть обіймати, зокрема, завідувач кафедри, професор, доцент, старший викладач, асистент, викладач-стажист. Така сама інформація міститься і в Законі «Про освіту», (стаття 55, пункт 1). Отже, держава регламентувала, що працівники ЗВО зобов'язані займатися науковою діяльністю (тільки посада викладача є суто педагогічною).

На нашу суб’єктивну думку, ситуація в Україні з науково-педагогічною діяльністю двояка. В ідеалі, за задумом держави, працівник вищої школи займається науковою діяльністю не заради власне науки, а для того, щоб збагатити власні знання, апробувати їх та ввести в навчальну програму. На практиці ж теми наукових статей та навчальних курсів, які викладає працівник, можуть суттєво різнитись. Та навіть ідеальна постановка питання має суттєву хибу: виходить, що науку науково-педагогічні працівники творять не заради істини, нових відкриттів, а вона набуває суб'єктно-орієнтованого, тунельного спрямування, тобто коли викладач пише науковий текст тільки заради власного збагачення, надолуження знань 3 конкретних дисциплін. Тоді постає питання: чому ці знання людина не може отримати з робіт інших науковців, а має продукувати власний текст? Ці питання лишаються відкритими для подальших наукових дискусій, а також для висунення нових гіпотез у лоні педагогіки, юриспруденції та філософії.

\section{На Вашу думку, чи і є факт публікації в журналі, індексованому у базі Scopus / Web of Science свідченням високого наукового рівня автора?}

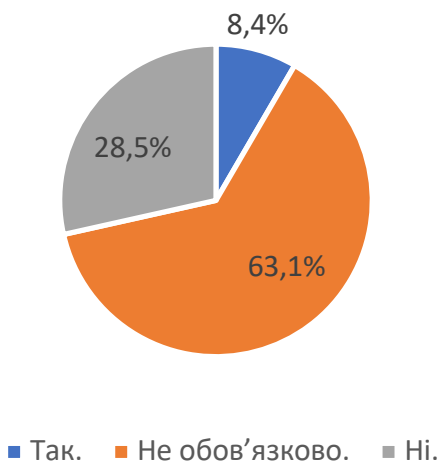

Рисунок 3.

Високий науковий рівень автора, про який ідеться в наступному питанні (рис. 3), - це питання наукометрії та квалітології науки. Ще й досі не існує єдиного ідеального параметра, 
за яким би точно можна було виміряти якість наукових доробків того чи іншого автора. На сьогодні (знову ж таки, перш за все 3 позиції держави), таким параметром виступає наявність або відсутність публікацій у наукометричних базах. Більшість респондентів - $63 \%$ та 28,5\% - фактично не погоджуються з таким станом речей, говорячи, що факт публікації y Scopus чи $\mathrm{WoS}$ не обов'язково $є$ (чи й зовсім не $\epsilon$ ) свідченням високого наукового рівня автора.

\section{Чому для Вас актуально мати публікацію в журналі, індексованому у базі Scopus / Web of Science?}
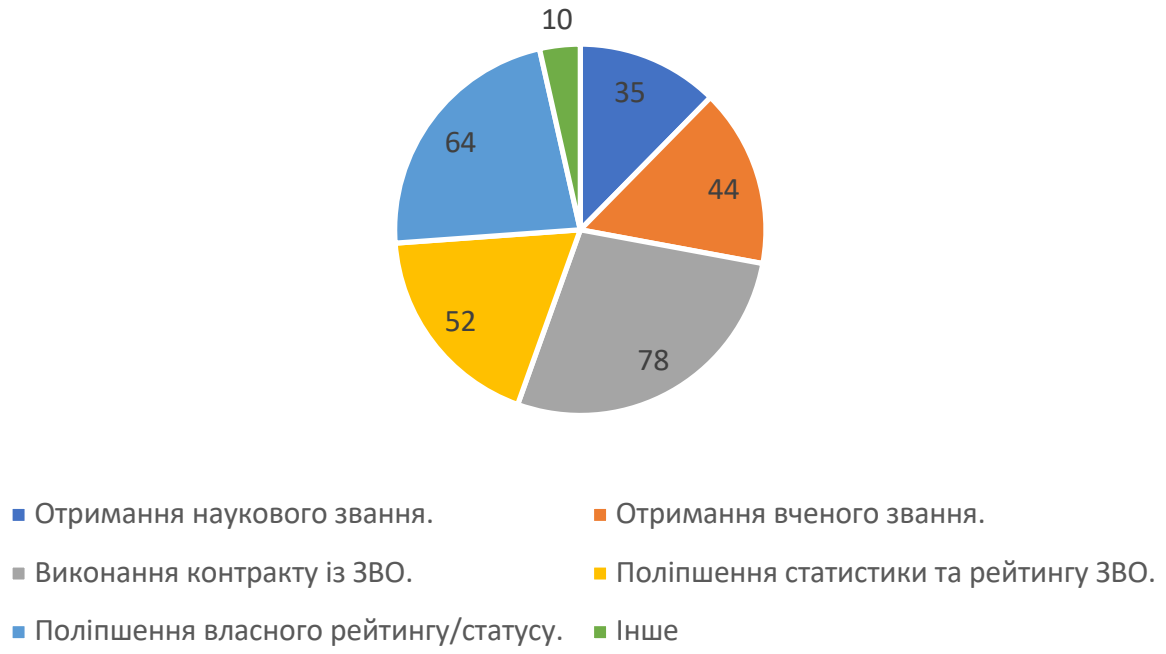

\section{Рисунок 4.}

Питання «Чому для Вас актуально мати публікацію в журналі, індексованому у базі Scopus / Web of Science?» (рис. 4) виступає маркером мотивації респондентів щодо публікування статей у наукометричних базах. На це запитання респонденти могли вказати декілька варіантів відповідей, тому тут числове значення не у відсотках. Найвагомішим мотивом (78 відповідей) для публікування респонденти визнали необхідність виконання контракту із ЗВО. Наступними за значущістю є відповіді про поліпшення статусу 3ВО та свого власного.

Зазначимо, що ті, хто обрав варіанти «виконання контракту із ЗВО», «отримання наукового ступеня» та «отримання вченого звання» керуються лише зовнішнім примусом. Таким чином, можемо констатувати, що у своїй більшості респонденти примушені публікуватися (157 відповідей). Також серед відповідей «інше» маємо дві відповіді, які також вказують на примус: «щоб мати роботу» та «вимога керівництва». 


\section{Чи справедливе твердження: «Науковці, які працюють у галузі «журналістика» («соціальні комунікації») та мають публікації в індексованих журналах, неохоче діляться інформацією, в яких саме»?}

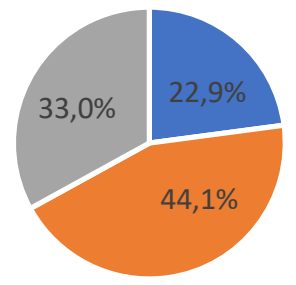

- Правильне. " Частково правильне. - Не правильне.

\section{Рисунок 5.}

У питанні про консолідованість наукової спільноти в галузі соціальних комунікацій щодо публікацій у наукометричних базах (рис. 5) відповіді «частково правильне» та «правильне» ми маркували як такі, що свідчать про наявність проблеми. Таке питання виникло з необхідності перевірити гіпотезу: важливість наявності статей у Scopus та WoS для проходження за нормативами різного порядку (отримання звань, рецензування та опонування, одержання і втримання посад) сьогодні настільки висока, а придатних журналів у галузі соціальних комунікацій настільки мало, що інформація про кожен із них уже становить цінність і дає перевагу іiі носію. Наша гіпотеза підтвердилася частково, адже, 3 одного боку, навіть невелике приховування чи спотворення інформації про відповідні журнали в наукометричних базах, в яких можна опублікувати матеріал, є маркером конкуренції спільноти у цьому питанні. 3 іншого боку, $31 \%$ опитуваних має вже опубліковану статтю, і абсолютна більшість із них дізналася про журнал саме від колег.

Важливим $\epsilon$ питання про труднощі публікування наукових матеріалів, їхню інтенсивність. Щоб встановити, з якими перешкодами найчастіше зустрічаються викладачі та здобувачі, ми запропонували оцінити фактори за шкалою, де 0 - фактор зовсім не має значення, а 5 - максимально впливовий (рис. 6). Найбільш значущим чинником, який утруднює публікування, респонденти назвали високу вартість публікації, на другому місці - відсутність будь-якої підтримки з боку держави у публікуванні статей, на третьому відсутність журналів у базах Scopus / Web of Science в Україні (у галузі «журналістика»). Фактори, які, на думку респондентів, мають найменше значення - необхідність кооперуватися з іншими авторами та низька якість поданих публікацій. Таким чином, респонденти більше відповідальності поклали на державу і зняли іiї із себе, вважаючи, що публікації подаються високої якості, тож якби була підтримка, то потрапляння до наукометричних баз було би набагато легшим. Найкращий варіант вбачається у потраплянні українських журналів з тематики галузі до Scopus / Web of Science. 


\section{Які фактори утруднюють можливість публікування в журналах, індексованих у базі Scopus / Web of Science? (за шкалою, де 0 - фактор зовсім не має значення, а 5 - максимально впливовий)}

Низька якість поданих матеріалів

Відсутність будь-якої підтримки з боку ЗВО у публікуванні статей

Відсутність будь-якої підтримки з боку держави у публікуванні статей

Необхідність кооперуватись з іншими авторами

Висока вартість публікації

Суттєва відмінність наукових шкіл (української та американської/європейської)

Відсутність журналів в базах Scopus / Web of Science в Україні (у галузі «журналістика»)

Незнання англійської мови.

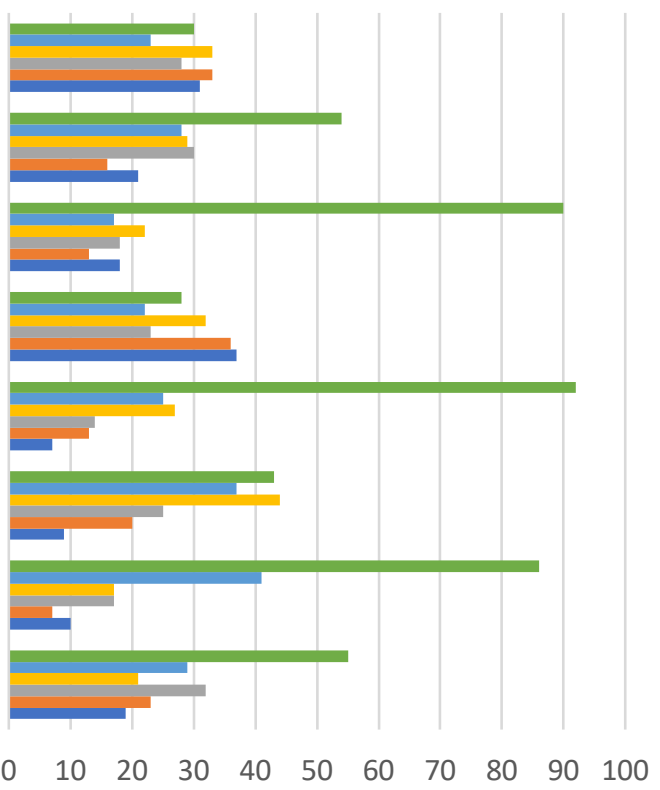

$\square 5 \square 4 \square 3 \square 2 \square 1 \square 0$

\section{Рисунок 6.}

Із 179 респондентів, які проходили анкетування, 56 уже мали опубліковану статтю в журналі, індексованому в базі Scopus / Web of Science (рис.7). Більшість із них (64\%) дізнались про журнал від колег, меншість (8,9\%) - через систему пошуку. Була можливість і розгорнутої відповіді. Так, одна людина відповіла, що вона сама засновник журналу в наукометричній базі; одна - що отримала запрошення на конференцію із можливістю публікування в журналі, який тоді був лише фаховим, а потім був включений у базу; одна що дізналась від іноземних колег (рис. 8). У $75 \%$ опитаних, що вже опублікували свої статті в індексованих журналах, матеріали були в співавторстві (рис. 9). Абсолютна більшість авторів (62,5\%) була вимушена доопрацьовувати публікацію (рис. 10). Найбільше статей було написано англійською мовою $(78,6 \%)$ (рис. 11). Процедура публікування статті (від іiі подання до публікування) зайняла у більшості від двох місяців до півроку, трохи менше статей автори опублікували за термін від шести місяців до року (рис. 12). 
Чи маєте Ви уже опубліковану статтю в журналі, індексованому у базі Scopus / Web of Science?

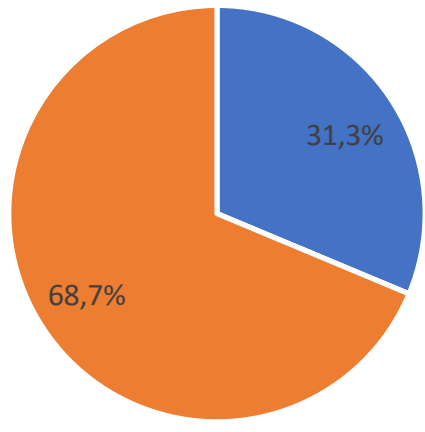

- Так $=\mathrm{Hi}$

Рисунок 7.

\section{Як Ви дізналися про журнал, у якому опублікувались?}

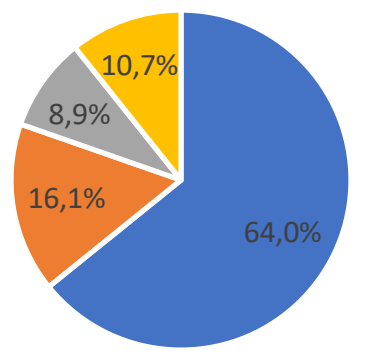

- Від колег.

- Із переліку журналів у самій базі.

— Через систему пошуку (Google чи інша). — Інше.

\section{Рисунок 8.}




\section{Опублікований матеріал був одноосібний чи у} співавторстві?

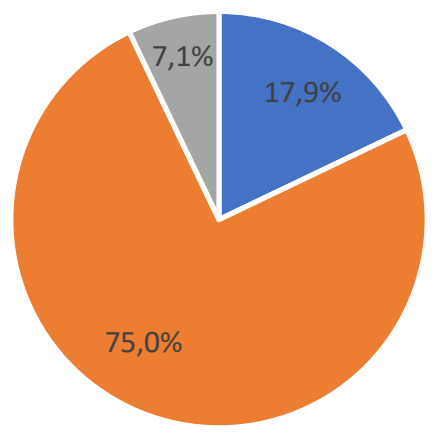

- Одноосібний. У співавторстві. - Одноосібний та у співавторстві.

\section{Рисунок 9.}

\section{Чи одразу була прийнята стаття до друку?}

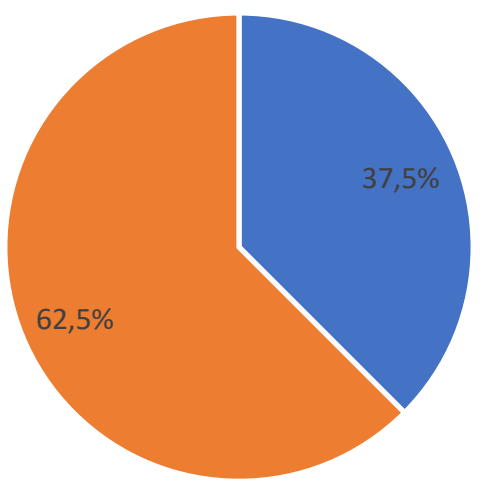

- Так. Ні, необхідно було доопрацьовувати.

\section{Рисунок 10.}




\section{Якою мовою була стаття?}

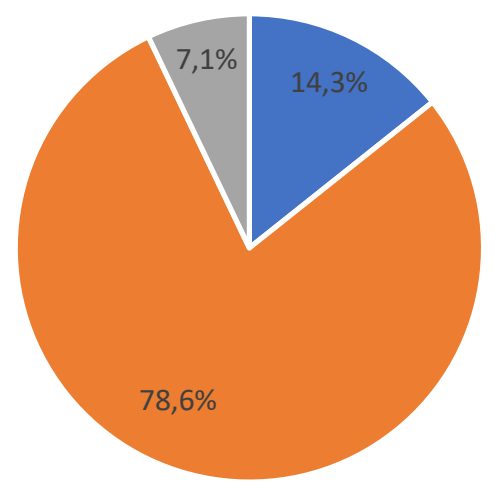

- Українською. Англійською. — Російською.

\section{Рисунок 11.}

\section{Скільки часу у Вас зайняла процедура публікування статті (від її подання до публікування)?}

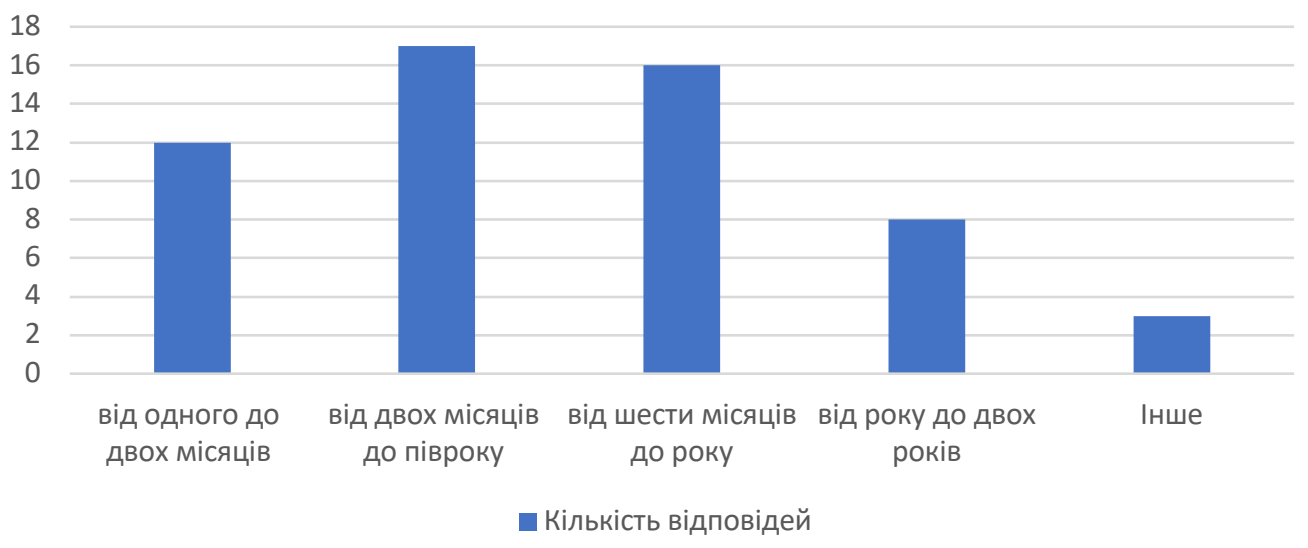

\section{Рисунок 12.}

Не мають опублікованої статті в Scopus / Web of Science 122 опитуваних. Із них майже $60 \%$ на час опитування шукають журнал для публікації, а 23,8\% не шукають тимчасово (рис. 13), що також свідчить про намір публікуватися, тільки менш інтенсивний. Водночас $84,4 \%$ зізналися, що поки не намагались подати свій науковий доробок в індексовані журнали (рис. 14). 


\section{Чи шукаєте Ви зараз журнал для публікації?}

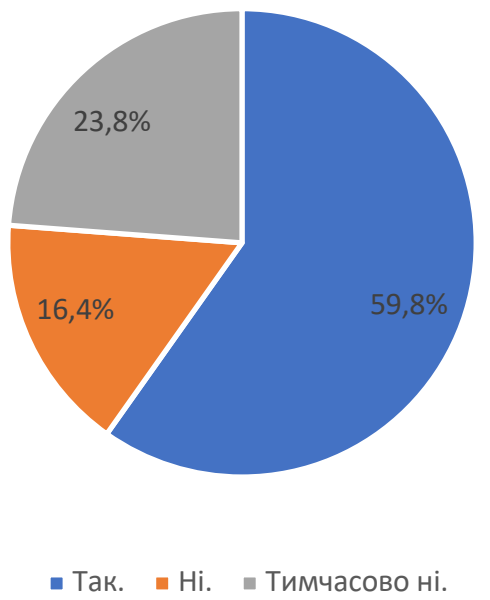

Рисунок 13.

\section{Чи вже намагалися Ви опублікуватись?}

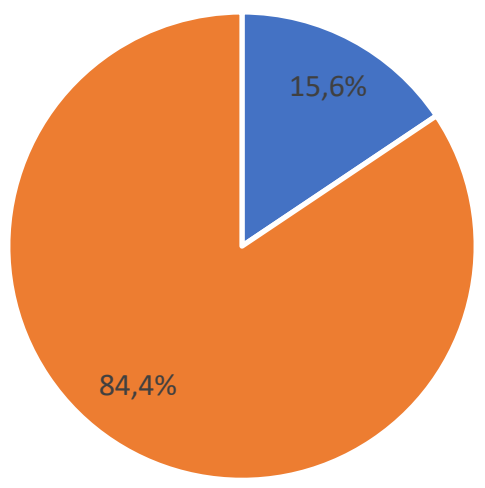

- Так, але статтю не прийняли. - $\mathrm{Hi}$.

Рисунок 14.

\section{Обговорення}

Державою встановлено, що всі науково-педагогічні працівники зобов'язані займатись науковою діяльністю. Не всі працівники галузі «журналістика» із цим погоджуються (34\% респондентів вважають, що людина має обирати, чи займатись науковою діяльністю, чи ні), 
при цьому, згідно з даними анкетування, більшість працівників примушені публікуватись. Ми додатково проаналізували звіт ректора Київського національного університету імені Тараса Шевченка, щоб встановити рівень зосередженості на значущості публікацій в індексованих журналах одного з найкращих ЗВО України.

Отже, 69 із 246 сторінок звіту ректора були присвячені статистиці наукометричних баз. Це 28\%, що є показовим, адже звіт ректора за рік охоплює всі сфери діяльності всіх інститутів і факультетів. Відзначимо також, що тема наукометричних баз включена до розділу звіту «Оцінювання наукової роботи», у якому йдеться про Scopus та Web of Science, а також про рейтинг Webometrix (аналізує не науково-освітню діяльність, а ступінь присутності ЗВО в інтернеті), при цьому останньому присвячено лише одну сторінку. Отож можна стверджувати, що для університету 99\% оцінки наукової роботи співробітників залежить суто від наявності чи відсутності статей у наукометричних базах.

Такий аналіз - кейсовий, не претендує на екстраполяцію результатів, однак показовий 3 огляду на контекст примусу та гіперболізованого акцентування на важливості й значущості публікацій у журналах Scopus / Web of Science.

При тому, що наукові й науково-педагогічні працівники примушені публікуватись, адекватні мотивувальні стимули відсутні. Якщо наша країна прагне впроваджувати світові моделі наукової та освітньої діяльності, вважаємо, варто запозичувати й мотиваційні, заохочувальні практики. «У багатьох країнах працюють державні програми, метою яких $\epsilon$ підвищення рейтингів і нарощування публікаційної активності. У розвинутих країнах стимулювальні виплати за наукові публікації закладено в заробітну плату. У країнах, що розвиваються, запроваджено спеціальні системи виплати винагород ученим за статті, опубліковані в журналах, що входять до баз даних WoS i Scopus. Подібні практики було впроваджено в Ірані наприкінці 1990-х років, у Туреччині, Зімбабве, Малайзії, Польщі» (Діденко, 2017, с. 90).

Натомість в Україні в галузі «журналістика», згідно з опитуванням, найвагомішими факторами, що утруднюють публікування, визнано високу вартість публікації та відсутність будь-якої підтримки з боку держави у публікуванні статей.

Водночас абсолютна більшість авторів (62,5\%) зізналась, що вони були вимушені доопрацьовувати публікацію, хоча фактор «низька якість публікації» визнаний респондентами найменш важливим у процесі публікування статей в індексованих журналах. Звідси випливає, що автори не хочуть визнавати, що рівень їхніх публікацій насправді не відповідає редакційним вимогам індексованих журналів, до того ж і самі визнають: кореляція між високим науковим рівнем автора та фактом публікації у Scopus чи WoS досить низька (або й зовсім відсутня).

Отже, ситуація з публікуванням матеріалів у журналах, що індексуються в базах Scopus та Web of Science, неоднозначна. Описана проблема потребує подальших досліджень i пошуку шляхів іiі вирішення, перш за все, на державному рівні. Тим, хто має намір публікуватись у журналах Scopus чи WoS, на цьому етапі можемо порадити послуговуватись такими середньостатистичними даними опитування: час прийняття до друку матеріалу - від двох місяців до пів року; мова більшості публікацій - англійська; найбільш охоче приймають статті, написані у співавторстві; найімовірніше дізнатися про необхідне видання - від колег.

\section{Список використаних джерел}

Діденко, Ю. В., \& Радченко А. І. (2017). Публікаційна активність як спосіб наукової комунікації та гонитви за рейтингами. Вісник Національної академії наук України, (9), 82-98. Режим доступу: http://nbuv.gov.ua/UJRN/vnanu_2017_9_11. (20.06.2021). 
Жабін, О. I. (2020). Консолідація показників українських учених, представлених у міжнародних наукометричних системах . Наукові пращі Національної бібліотеки України імені В. І. Вернадського, 2020 (60), 200-211.

Старостіна, А. О., Осецький, В. Л., \& Кравченко, В. А. (2018). Оцінка результатів наукової діяльності в класичних університетах підприємницького типу в умовах євроінтеграції. Вісник Киівського національного університету ім. Тараса Шевченка. Серія: Економіка, (4 (199)), 35-45. doi: 10.17721/1728-2667.2018/199-4/5

Тарасевич, Ю. Ю. \& Шиняева, Т. С. (2015). Критерии оценки состояния и развития научных исследований на основе анализа наукометрической информации. Bonpocbl образования, (2), 2. URL: https://cyberleninka.ru/article/n/kriterii-otsenki-sostoyaniya-irazvitiya-nauchnyh-issledovaniy-na-osnove-analiza-naukometricheskoy-informatsii (дата (01.06.2021).

Статтю подано до редакції 07.05.2021

\section{References}

Didenko, Y. V., \& Radchenko, A. I. (2017). Publication activity as a way of scientific community and pursuit of ratings. Bulletin of the National Academy of Sciences of Ukraine, (9), 8298. Retrieved from http://nbuv.gov.ua/UJRN/vnanu_2017_9_11. (20.06.2021)

Starostina, A. O., Osetskyi, V. L., \& Kravchenko, V. A. (2018). Evaluation of the results of scientific activity in classical universities of entrepreneurial type in the conditions of European integration. Bulletin of Kyiv National University named after Taras Shevchenko, 4(199), 35-45. doi: 10.17721/1728-2667.2018/199-4/5

Tarasevich, Yu.Yu. \& Shinyaeva, T. S. (2015). Criteria for assessing the state and development of scientific research based on the analysis of scientometric information. Educational issues, (2), 2. Retrieved from https://cyberleninka.ru/article/n/kriterii-otsenki-sostoyaniya-irazvitiya-nauchnyh-issledovaniy-na-osnove-analiza-naukometricheskoy-informatsii. $(01.06 .2021)$

Zhabin, O. I. (2020). Consolidation of indicators of Ukrainian scientists, represented in international scientometric systems. Scientific works of the National Library of Ukraine named after VI Vernadsky, 2020(60), 200-211.

Submitted 07.05.2021 